\title{
A Arbitragem Comercial como Fator de Renovação do Direito Internacional Privado Brasileiro dos Contratos*
}

\section{Fabio Morosini**}

\section{Introdução}

Em nome dos benefícios da vantagem comparativa (comparative advantage), a tendência de aumento do fluxo comercial entre países é bastante óbvia. Além disso, a consolidação de blocos comerciais, tal qual o Mercosul, fortifica o intercâmbio dos países-membros, indo de encontro ao macro-objetivo de desenvolvimento econômico de todos que deles participam. Por outro lado, o direito desses países pode colaborar ou dificultar a liberalização comercial. O direito colabora através de políticas liberais de comércio internacional e respeito pela prática jurídica dos parceiros comerciais, ou dificulta a troca comercial entre partes internacionais quando, de forma provinciana (parochial), desatenta das necessidades dos seus cidadãos e do papel desses na comunidade comercial internacional.

Neste sentido, observa-se que a prática da contratação internacional toma contornos cada vez maiores. Se antes transacionar com parceiros estrangeiros não era necessariamente exercício comum entre empresas, hoje a contratação internacional já se banalizou por meio do comércio eletrônico. A barreira geográfica que se apresentava como um obstáculo à contratação internacional foi rompida pela facilidade proporcionada pelo espaço virtual.

Neste artigo, parte-se da idéia que a principal legislação de direito internacional privado (DIPr) brasileira, is to é, a Lei de Introdução ao Código Civil (LICC), de 1942, está defasada no que tange a sua aplicação à prática obrigacional, não suprindo as demandas dos atores do comércio internacional. $\mathrm{O}$ artigo $9^{1}$, que trata das regras conflituais em matéria de obrigações, é rígido quanto aos elementos de conexão "disponíveis" às partes e, salvo melhor juízo, exclui a autonomia da vontade desse rol de elementos. O problema que surte dai, em perspectiva de comércio intemacional, é que as partes não podem escolher a lei aplicável às

\footnotetext{
* Palestra proferida no Curso de Especialização em Direito Contratual da PUC-SP, em 9 de novembro de 2005. Meus agradecimentos, pelo convite, aos Professores Nelson Nery Jr. e Clarissa Ferreira Macedo D'Isep, coordenador e assistente da coordenação respectivamente.

* Professor substituto da Faculdade de Direito da UFRGs; advogado; Ph.D. e mestre pela Escola de Direito/Instituto de Estudos Latino-Americanos da Universidade do Texas em Austin (EUA); mestre em direito da globalização econômica pela Universidade de Paris I (Panthéon-Sorbonne) e pelo Instituto de Estudos Políticos de Paris (Sciences Po) (França); e especialista em direito internacional pela UFRGS. Gostaria de agradecer às Professoras Cláudia Lima Marques e Nadia de Araujo e ao Professor Diego P. Fetnández Arroyo pelos comentários oferecidos a versões anteriores deste artigo. Todos os eventuais erros constantes deste artigo são de inteira responsabilidade do autor. E-mail: fmorosini@hotmail.com.

1 Artigo 9 da LICC:

"Para qualificar e reger as obrigações, aplicar-se-á a lei do país em que se constituírem.

Parágrafo 1 - Destinando-se a obrigação a ser executada no Brasil e dependendo de forma essencial, será esta observada, admitidas as peculiaridades da lei estrangeira quanto aos requisitos extrínsecos do ato.

Parágrafo 2 - A obrigação resultante do contrato reputa-se constituída no lugar em que residir o proponente."
} 
suas obrigações contratuais, dependendo das regras de conexão neutras constantes do artigo 9 da LICC. Na prática, tal situação resulta em desconforto em nossos parceiros estrangeiros que, muitas vezes, temem um resultado desvantajoso numa eventual disputa, por consequêencia do direito aplicável por indicação da LICC.

Uma opção mais consentânea com os anseios do comércio internacional seria o reconhecimento da autonomia da vontade como elemento de conexão, pois permitiria que um direito que é visto como mais apropriado em caso de eventuais disputas fosse escolhido livremente pelas partes. E, acreditando-se que tal opção fosse causar maior previsibilidade no resultado dessas controvérsias e conseqüente aumento no tráfego comercial internacional, argumenta-se que, ao longo prazo, experimentaríamos significativo desenvolvimento econômico e aumento de bemestar (welfare).

Mas, se por um lado a LICC impede que alcancemos esses objetivos de forma direta, em razão de sua rigidez, por outro, começa-se a observar maneiras alternativas de se alcançar os objetivos almejados por via da arbitragem comercial. A tarefa desse artigo então é simples. A partir do pastulado que a arbitragem comercial é um contrato internacional - talvez o seu exemplo mais proeminente, eu mostro que está nela a maneira de superar os entraves à liberdade contratual no contexto internacional, relativos ao impedimento da escolha de lei aplicável.

A tese subjacente ao presente artigo é que a arbitragem comercial internacional, legitimada enquanto contrato, renova o DIPr brasileiro dos contratos, superando as limitações impostas pelo artigo 9 da LICC.

$\mathrm{O}$ artigo está dividido em duas partes. $\mathrm{Na}$ primeira delas, cuido das questõeschave em sede de contratos internacionais, quais sejam: eleição de foro, lei aplicável e autonomia da vontade (ou a falta desta). $\mathrm{Na}$ segunda parte, mostro como a arbitragem comercial internacional nada mais é do que um contrato internacional, atentando-se para algumas de suas principais peculiaridades - contratuais, diga-se de passagem da competência-competência, separabilidade e arbitrabilidade. Enquanto contrato internacional, a arbitragem comercial desafia as limitações da LICC.

\section{Os Contratos Internacionais no Direito Brasileiro}

Se me proponho a defender a tese segundo a qual a arbitragem comercial internacional é um contrato internacional, como no Brasil assim o entendemos, nada mais lógico do que começar por explicar o que é um contrato internacional, fazendo sua reconstrução conceitual com base na doutrina e na jurisprudência mais relevantes. 
Nadia de Araujo, buscando uma definição para contrato internacional, conclui que o que o caracteriza "é a presença de um elemento de estraneidade que o ligue a dois ou mais ordenamentos jurídicos nacionais." "2 Assim, a internacionalização de um contrato se dá pelo fato de uma das partes residir em país estrangeiro ou que o contrato tenha a sua celebração e execução em países diferentes. ${ }^{3}$

O estudo dos contratos internacionais no direito brasileiro é tradicionalmente consagrado pela summa divisio entre eleição de foro e escolha de lei aplicável. Por razões didáticas, aceitarei essa "fotografia" do direito dos contratos internacionais para legitimar a minha tese sobre o caráter renovador da arbitragem comercial internacional para o DIPr brasileiro dos contratos.

A distinção entre eleição de foro e lei aplicável é fundamental, pois, em que pesem terminologicamente parecidas, exercem funçães auxiliares, mas diversas. A primeira - de direito processual - aponta para qual autoridade judiciária será competente para analisar a disputa oriunda do contrato. Já a questão referente à lei aplicável - de direito material - refere-se a qual direito será aplicável à controvérsia. Note-se que em função das regras conflituais de DIPr, o juiz competente não necessariamente aplicará o seu direito material à disputa, a depender do elemento de conexão da obrigação contratual, como o direito do lugar da celebração do contrato, da execução da obrigação, da residência do ofertante, etc. Começarei tratando a questão da eleição de foro (Parte 1), para depois abordar a escolha do direito aplicável em sede de contratos internacionais (Parte 2).

\section{Eleição de Foro}

A eleição de foro, diferentemente do direito aplicável, é tema de direito processual internacional e interno. Aqui, busca-se delimitar a jurisdição competente para processar e julgar uma demanda acerca de um contrato internacional. Diferentemente também do instituto do direito aplicável ao contrato, a eleição de foro pelas partes é aceita no direito brasileiro por força do artigo 111 do Código de Processo Civil Brasileiro (CPC). ${ }^{4}$ Ainda, a eleição de foro mantém relações mais diretas com o estudo da competência internacional, constantes dos artigos 88 a 90 do CPC.

artigo 88 do CPC taxa as situações nas quais a autoridade judiciária brasileira é concorrentemente competente para processar e julgar uma determinada demanda. Assim, estipula que a autoridade judiciária brasileira poderá declarar-se competente em disputas que o réu, qualquer que seja a sua nacionalidade, encontre-se domiciliado

\footnotetext{
ARAUJO, Nadia de, Direito Internacional Privado: Teoria e Prática Brasileira, Rio de Janeiro, Editora Renovar, 2003, p. 312 Id.

4 Artigo 111 do CPC:

A competência em razão da matéria e da hierarquia é indexrogável por convenção das partes; mas estas podem modificar a competência em razão do valor da causa e do território, elegendo foro onde serão propostas as ações oriundas de direitos e obrigações.

Veja também o entendimento do STF na Súmula 335: "É válida a cláusula de eleição de foro para os processos oriundos do contrato."
} 
no Brasil (inciso I), no Brasil deva ser cumprida a obrigação (inciso II), ou quando a ação se origine de fato ocorrido ou ato aqui praticado (inciso III). Por último, será igualmente concorrente a competência da justiça brasileira sobre pessoa juridica ré que no Brasil tiver agência filial ou sucursal (parágrafo único). ${ }^{5}$

5 A jurisprudência é vasta. Veja, por exemplo, aceitando a prorrogação da competência: TJ/RS, Ag. 70005228440, 19a. Câmara Civel, julgamento em 8/4/03; "Agravo de instrumento. Competência internacional. Jurisdição concorrente. Foro de eleição. Ilícito contratual. $O$ foro local não é o competente, eis que o contrato firmou a competência do Unguai para eventual demanda, que ora se processa. Não há como se relativizar a competência do foro, eis que os agravados não são hipossuficientes - são autores de outras ações de porte que corre em primeiro grau —, podendo se deslocarem ao foro do Uruguai para se defenderem na demanda que ajuizaram contra o agravante. Agravo provido." Mas veja:

TJ RJ 2003.001. 03058. 11a. CC. COMPETÊNCIA CONCORRENTE. FORO DE ELEIÇÃO DE JUSTIÇA ESTRANGEIRA. Se a empresa ré, sediada no Brasil, sub-rogou o contrato de distribuição celebrado com outra empresa também domiciliada no Brasil, inequívoca a competência da Justiça Nacional para o processamento e julgamento da demanda, ainda que haja cláusula de eleição de foro estipulando os Tribunais de Madri para o exame da matéria. Demais disso, a hipótese versada nos autos é de competência intemacional concorrente do Juiz Brasileiro, não podendo ser afastada pela vontade das partes, na medida em que está diretamente relacionada com a soberania nacional. Recurso Provido. TRANSPORTE MARÍTIMO. EMENDA CONSTITUCIONAL 7/77. AÇÃO RESCISÓRIA. COMPETÊNCIA RESIDUAL DO EXTINTO TRIBUNAL FEDERAL ELEIÇÃO CONTRATUAL DE FORO ESTRANGEIRO. PREVALÊNCIA DA JURISDIÇÃO BRASILEIRA. APLICAÇÃO SO ART. 88, II, DO C.P.C. E DO PRINCÍPIO DA SUBMISSÃO 1. (...) 2. Não prevalece o foro contratual eleito pelas partes quando, pela obrigação assumida pela empresa de transporte, o desembarque da mercadoria é feito no Brasil. Aplicação do artigo 88, inciso II, do Código de Processo Civil, bem como do princípio da submissão em razão da anterior aceitação da jurisdição brasileira. (STJ. Ação Rescisória n. 133/RS. 2a Seção. Rel. Min. Cláudio Santos, j. 30/08/1989). COMPETENAIA INTERNACIONAL. JURISDIÇÃO CONCORRENTE. AÇÃO VERSANDO SOBRE CONTRATO QUE SE PRESUME CELEBRADO NO BRASIL. ELEIÇÃO DE FORO ESTRANGEIRO ADMISSÍVEL. CLÁUSULA QUE, PORÉM, NÃO AFASTA A JURISDIÇÃO BRASILEIRA. EXCEÇÃO DE INCOMPETÊNCIA REJEITADA. APLICACÃO DOS ARTS. 88, DO CPC E 1.087 DO CC.Tratando-se de ação versando sobre contrato que, a teor do art. 1.087 do CC, se presume celebrado no Brasil: em tema de competência intemacional, se está diante da jurisdição concorrente, que admite a atuação paralela da jurisdição estrangeira sobre a mesma causa sujeita à jurisdição brasileira. Assim, embora válida a eleição de um foro alienígena, é inaceitável que tal cláusula afaste a jurisdição nacional cuja autoridade não está impedida de apreciar a matéria. (TJSP. AI 8.275-0. C. Esp. Rel. Nóbrega de Salles, unânime, j. 16.06.1988). COMPETÊNCIA INTERNACIONAL. CONTRATO DE CONVERSÃO DE NAVIO PETROLEIRO EM UNIDADE FLUTUANTE. GARANTIA REPRESENTADA POR "PERFOMANCE BOND" EMITIDO POR EMPRESAS ESTRANGEIRAS. CARÁTER ACESSÓRIO DESTE ÚLTIMO. JURISDIÇÃO DO TRIBUNAL BRASILEIRO EM FACE DA DENOMINADA COMPETÊNCIA CONCORRENTE (ART. 88, INC. II, DO CPC). O "Performance bond" emitido pelas empresas garantidoras é acessório em relação ao contrato de execução de serviços para a adaptação de navio petroleiro em unidade flutuante de tratamento, armazenamento e escoamento de óleo e gás. - Caso em que empresas as garantes se sujeitam à jurisdição brasileira, nos termos do disposto no art. 88 , inc. II, do CPC, pois no Brasil é que deveria ser cumprida a obrigação principal. Competência internacional concorrente da autoridade judiciária brasileira, que não é suscetível de ser arredada pela vontade das partes. - $\dot{A}$ justiça brasileira é indiferente que se tenha ajuizado ação em país estrangeiro, que seja idêntica a outra que aqui tramite. Incidência na espécie do art. 90 do CPC. Recurso especial ñão conhecido, prejudicada a medida cautelar. (ST). $4 \mathrm{~T}$. Rel. Min. Barros Monteiro. Unânime. J. 08/08/2000). AGRAVO DE INSTRUMENTO. COMPETÊNCIA INTERNACIONAL. CONTRATO DE REPRESENTAÇÃO COMERCIAL. RESCISÃO UNILATERAL PELA REPRESENTADA. FORO DE EIEIÇÃO, SEDIADO EM PAIS ESTRANGEIRO. Não se pode considerat, como livremente convencionada, clausula de contrato de representação comercial, em que se adotou foro de eleição, sediado em pais estrangeiro, - qual só atende 'as conveniências e interesses da representada. Isso equivale a privar, virtualmente, o representante, parte economicamente mais fraca, de postular a tutela jurisdicional, com reais prejuizos a seus direitos, o que e' razão suficiente, para se afastar o foro de eleição. Nessa situação, segue-se a disciplina juxídica brasileira, que estabelece, na lei de regência, que o foro competente e'o do domicilio do representante, nas demandas dai' originarias. Provimento do recurso. (WLS) Ementa do voto vencido do JDS. Des. Murilo Andrade de Carvalho: COMPETÊNCIA INTERNACIONAL. COMPETÊNCIA CONCORRENTE. CPC, ART. 88. FORO DE ELEIÇÃO. VALIDADE. CONTRATO DE REPRESENTAÇÃO COMERCIAL. Submetendo as partes seus interesses contratuais ao direito francês e elegendo um dos foros daquele pais para dirimir as controvérsias a respeito, reconhece-se a validade dessa eleição, que retira da justiça brasileira o conhecimento de situação conflituosa, desde que, como ocorreu, houve o levantambento da exceção pela parte re'. Improvimento do recurso, como voto vencido. (TJRJ AI 1998.002.01190. 8a CC. Rel. Des. Luiz Odilon Bandeira. J. 19/05/1998). 
O artigo 89 do CPC elenca as hipóteses de competência exclusiva da autoridade judiciária brasileira, quais sejam ações relativas a imóveis situados no Brasil (inciso I) e a inventário e partilha de bens situados no Brasil (inciso II).

Por último, o artigo 90 dispõe sobre a não existência da litispendência internacional nos seguintes termos: "A ação intentada perante tribunal estrangeiro não induz litispendência, nem obsta a que a autoridade judiciária brasileira conheça da mesma causa e das que lhe são conexas."

Questões relativas a litispendência internacional no contexto latino-americano ainda não são tão preocupantes como o são em direito europeu. Lá, uma das discussões mais ferrenhas travadas atualmente é no que diz respeito à litispendência internacional versus os institutos do forum non conveniens e anti-suit injunction, ambos com origem no direito inglês.

$O$ instituto do forum non conveniens prevê a possibilidade do juiz, mesmo que competente, livremente declinar de sua competência caso a entenda inapropriada. ${ }^{6}$ Já o instituto do anti-suit injunction ocorre toda vez que o juiz usa de sua competência para impedir o seguimento de demanda proposta no exterior. ${ }^{7}$ Em tempos de uniformização do direito internacional privado europeu, a sólida aceitação acerca da inexistência de litispendéncia internacional nos países de tradição civilista choca-se com a sua permissão no direito da common law. $^{8}$ Este comentário de direito comparado justifica-se pois, em face da crescente globalização econômica, estamos cada vez mais sujeitos a lidar com direitos estrangeiros, além daqueles dos nossos vizinhos geográficos. Por outro lado, serve também para introduzir o tema da conveniência de foro no direito brasileiro.

No Brasil, a prorrogação da competência é permitida quando inexiste fraude à lei, violação aos princípios de ordem pública, desatenção aos lindes da liberdade contratual ou ofensa aos princípios fundamentais de direito das obrigações em matéria contratual. ${ }^{9}$ Todavia, a prorrogação da competência será vedada toda vez que o foro eleito não possuir qualquer conexão pelo direito processual internacional brasileiro. ${ }^{10}$

\section{Lei Aplicável}

Uma vez enfrentada a questão mais ampla de qual juiz ou tribunal será competente para processar e julgar a demanda envolvendo uma controvérsia contratual,

\footnotetext{
6 Material de aula do curso sobre direito internacional privado europeu, ministrado pela Professora Horatia Muir Watt, na Faculdade de Direito da Universidade de Paris I (Panthén-Sorbonne), no primeiro semestre de 2004 (arquivado com o autor). 7 Id.

8 Sobre a dificuldade da convergência do direito europeu, veja Pierre Legrand, Eunopean Legal Systems. Are Not Converging, 45 INT'L \& Comp. L.Q. 55 (1996). Veja também minha contribuição sobre o impacto do direito comunitário europeu no direito intemacional privado dos Estados-Membros em Lan do Globalization: Beyond Traditional Methodology of Comparative Legal Studies and an Example from Private International Law, CARDOZO J. INT'L \& COMP. L. (no prelo)

? José Inácio Gonzaga Franceschini, A Lei e o Foro de Eleição em Tema de Contratos Internacionais, in in RODAS, João Grandino, Contratos Internacionais, 3. ed. São Paulo: Editora Revista dos Tribunais, 2002. p. 101.

${ }^{10}$ Id. p. 102
} 
deve o juiz ou o tribunal recorrer das regras de DIPr para descobrir qual o direito material aplicável ao caso. Aqui, de acordo com as regras conflituais vigentes, deve a autoridade judiciária aplicar o disposto no artigo $9 \mathrm{da}$ LICC.

O artigo 9 da LICC, ao cuidar dos elementos de conexão aplicáveis em matéria obrigacional, é taxativo (e limitativo) quanto à liberdade das partes contratantes em escolher a lei aplicável às suas obrigações. Assim, as obrigações serão qualificadas e regidas pela lei do país em que se constituírem, ou seja, pela lei do lugar da celebração do contrato (Caput do artigo 9 da LICC) ${ }^{11}$.

Talvez a maior falha do caput do artigo 9 da LICC foi em não ter contemplado a autonomia da vontade das partes. Como informa Nadia de Araujo, "autonomia da vontade no DIPr, utilizada nos Contratos Internacionais' nada tem a ver com o que os civilistas gostam de chamar de 'autonomia privada', e que diz respeito à faculdade das partes de contratar. Para o DIPr, autonomia da vontade significa permitir que as partes escolham a lei aplicavel ao contrato internacional."12

Note-se que o artigo 13 da revogada LICC de 1916 permitia a autonomia da vontade das partes ao dispor que: "Regulará, salvo estipulação em contrário, quanto à substância e aos efeitos das obrigações, a lei do lugar onde foram contraídas." (Grifos meus). Para Serpa Lopes, ${ }^{13}$ a interpretação mais correta da expressão salvo estipulação em contrário consagrava a teoria da autonomia da vontade.

Uma vez adotada, seja em convenções internacionais ou nas regras conflituais de um sistema de direito nacional, a autonomia da vontade assume a função de elemento de conexão. ${ }^{14}$ Dentre as vantagens oferecidas pela teoria da autonomia da vontade, ressalta-se a flexibilização das regras de conflito de leis, a previsibilidade e conseqüente segurança jurídica como sendo as mais relevantes.

Essas ditas vantagens estão todas interligadas e por isso uma explicação em conjunto. Uma crítica que se pode fazer ao sistema de direito internacional privado brasileiro é com relação ao seu demasiado formalismo processual e rigidez. Por conseguinte, a liberdade das partes limita-se a uma liberdade de ação, presente na escolha do lugar onde o contrato será celebrado e onde será executado. Feitas essas escolhas, caberá ao DIPr dizer qual a lei regerá as obrigações oriundas do contrato.

A American Revolution foi contra esse formalismo e buscou alcançar a justiça material, em rebeldia ao rígido arcabouço procedimental de tradição continental européia. ${ }^{15}$

11 STJ - ACÓRDÃO: RESP 97099/RS (9600343276). Contrato de de corretagem. Lei aplicável art. 9. da LICC. A obrigação derivada desse contrato considera-se constituida no pais em que concluido, embora possa a obrigação de pagar estar sujeita à condição do bom êxito da intermediação. Não releva, assim, que a compra e venda se tenha feito no exterior, se a prestação de serviços foi contratada no Brasil. R.: M. Eduardo Ribeiro.

12 ARAUJO, Nadia de, Contratos Internacionais e a Jurisprudência Brasileirai Lei Aplicárel, Ondem Pública e Cláusula de Eleigão de Fono, in RODAS, João Grandino, Contratos Internacionais, 3. ed. São Paulo: Editora Revista dos Tribunais, 2002. p. 197.

13 LOPES, Serpa, Apud RODAS, João Grandino, Elementos de Conexão do Direito Internacional Privado Brasileiro Relativamente às Obrigações Contratuais, in RODAS, João Grandino, Contratos Internacionais, 3. ed. São Paulo: Editora Revista dos Tribunais, 2002. p. 50-51.

14 ARAUJO Nadia de, Contratos Internacionais: Autonomia da Vontade, Mercosule Convengöes Internacionais, 3. ed. Rio de Janeiro: Editora Renovar, 2004.p. 22.

15 Para um apanhado sobre a American Rerolution em DIPr dos Estados Unidos, veja ARAUJO, Nadia de, Direito Internacional Privado: Teoria e Pratica Brasileira, Rio de Janeiro, Editora Renovar, 2003, pp. 40 e seguintes. 
Nesse sentido, a autonomia da vontade age de forma a permitir que as partes escolham a lei aplicável ao seu contrato, fugindo dos elementos de conexão estanques, tais quais o do lugar da celebração do contrato e o da execução da obrigação. A teoria da autonomia da vontade aplicada ao DIPr brasileiro permitiria que as partes, por exemplo, escolhessem, para reger a obrigação contratual, em vez do direito do lugar da celebração do contrato, o lugar de sua execução, caso as partes entendessem ser o direito do local da execução mais em conta dos seus interesses. Note-se, entretanto, que o exemplo é ainda conservador, pois a teoria da autonomia da vontade bem permitiria a escolha de um direito que nenhuma conexão mantém com a relação contratual, tal como observa-se da prática arbitral internacional.

Por conseqüência dessa maior flexibilidade propiciada pela autonomia da vontade enquanto elemento de conexão para obrigações oriundas do contrato, tem-se uma maior previsibilidade com relação ao direito aplicável. Dito de outra forma, não ficam as partes à inteira dependência do sistema de direito onde foi celebrado o contrato, no caso do caput do artigo 9 da LICC. Essa previsibilidade vem necessariamente acompanhada de segurança jurídica, que é ofertada aos contratantes. Nesse sentido, a autonomia da vontade funciona como um atrativo de forma a aumentar o fluxo de transações comercias entre partes brasileiras e estrangeiras. É bem evidente que partes estrangeiras atualmente mostram-se reticentes em transacionar com partes brasileiras, via autoridade judiciária brasileira, em função da imprevisibilidade do direito aplicável. A inclusão da autonomia da vontade enquanto elemento de conexão eliminaria esse chilling effect ocasionado pela atual redação e aplicação do artigo 9 da LICC.

Já no que tange à forma da obrigação, reza o parágrafo 1 do artigo 9 da LICC que: "Destinando-se a obrigação a ser executada no Brasil e dependendo de forma essencial, será esta observada, admitidas as peculiaridades da lei estrangeira quanto aos requisitos extrinsecos do ato." Em outras palavras, observar-se-á a lei do lugar da execução cumulada com a lei do lugar da celebração quanto aos requisitos extrínsecos do ato. Por uma questão de celeridade contratual, poder-se-ia argumentar pela simplificação do parágrafo 1 do artigo 9 da LICC, ao dispor como aplicável à forma do ato apenas o direito de um lugar, seja o do lugar da celebração ou o da execução da obrigação contratual, por exemplo. Mais ousado seria deixar que as próprias partes elegessem a lei aplicável à forma do ato, via autonomia da vontade, de forma que estas poderia mesmo escolher como aplicável o direito de um terceiro país não conectado com a relação contratual. Por outro lado, se buscamos celeridade nas resoluções das disputas oriundas de obrigações contratuais, talvez fosse mais lógico advogar por um sistema conflitual unitário, contra o depéçage, de maneira que um único elemento de conexão seria aplicável à obrigação contratual, aqui incluída a forma do ato.

Por último, em se tratando de obrigação contraída entre ausentes, is to é, quando as partes não se encontram fisicamente para celebrar o contrato, reputa-se aplicável o direito do lugar da residência do proponente (parágrafo 2 do artigo 9 da LICC) ${ }^{16}$.

16 TARS: Rec NÚMERO: 195157003 DATA 27/03/1996. TRANSPORTE DE MERCADORIAS. COMPROVAÇ̃̃O DA 
Conforme explica João Grandino Rodas, a conexão pelo domicílio imporia uma rigidez não desejada à relação contratual, de maneira que "o elemento de conexão residência é mais consentâneo com a mobilidade dos negócios, devendo o mesmo ser considerado com elasticidade."17

É verdade que as relações negociais clamam por um tratamento que atenda as necessidades que lhe são peculiares. Nesse sentido, a justificativa do elemento de conexão residência procede. Entretanto, o parágrafo 2 do artigo 9 da LICC não se aplica apenas a transações business-to-business, o que lhe demanda um tratamento genérico para agregar também, por exemplo, relações obrigacionais entre partes em condições desiguais, tal como as transações business-to-consumer. ${ }^{18}$ Assim, as relações entre fornecedor e consumidor no plano internacional estão insuficientemente tuteladas para zelar pelos interesses e direitos do contratante consumidor.

O problema central constante do parágrafo 2 do artigo 9 para o consumidor é que ao eleger a residência do proponente como elemento de conexão para obrigação contraída entre ausentes, isto significa dizer que o direito do lugar da residência do fornecedor sempre será aplicado. ${ }^{19}$ A dificuldade está nos limites que tal "escolha" impõe ao consumidor. Nesses tipos de transações, o consumidor encontra-se em desigualdade de condições econômicas e de informação, muitas vezes impedindo que o consumidor tenha acesso à justiça por impossibilidade econômica de se deslocar fisicamente até o foro do fornecedor, afora as questões lingǘsticas que freqüentemente se apresentam nesses tipos de contrato como mais um elemento impeditivo do acesso do consumidor à justiça. ${ }^{20}$

Para sanar as imprecisões constantes do parágrafo 2 do artigo 9 da LICC, Cláudia Lima Marques conclui pela necessidade de uma Convenção Interamericana de Direito Internacional Privado (CIDIP) sobre a lei aplicável a alguns contratos e relações de consumo. ${ }^{21}$ Como elemento de conexão, a autora do projeto de CIDIP sugere a autonomia da vontade limitada. ${ }^{22}$

Por outro lado, nem mesmo para as relações business-to-business o elemento de conexão residência do proponente se afigura como o mais propício. Se a mobilidade

ENTREGA DIREITO aplicável segundo o ordenamento jurídico brasileiro, lei de Introdução ao Código Civil, em referencia, (art. 9 e par-2), o cumprimento da obrigação reger-se-a pela lei do pais onde se constitui e, quando resultante de contrato, reputa-se constituída no lugar em que residir o proponente. Não importa que no contrato de transporte a entrega da mercadoria tenha ocorrido em pais estrangeiro. A aplicação da lei brasileira decorre do fato de que a obrigação aqui se constitui e onde reside o proponente. Por sua vez, o conhecimento de transporte e o documento próprio e hábil para comprovar o recebimento de mercadoria. A entrega pelo transportador por outro modo, arguïndo as exceçôes do Decreto n.2045 4/31, não tem aplicação ao caso concreto.

17 RODAS, João Grandino. Op. Cit., p. 55

18 Para uma crítica detalhada sobre o DIPr brasileiro, em especial o artigo 9 da LICC, e as relações de consumo internacional, veja MARQUES, Cláudia Lima, A Insuficiente Protejäo do Consumidor nas Normas de Direito Internacional Privado - Da Necessidade de uma Convenģão Interamericana (CIDIP) sobre a Let Aplicárel a Alguns Contratos e Relaçöes de Consumo, in MARQUES, Cláudia Lima \& ARAUJO, Nadia, O Noro Direito Internacional: Estudos em Homenagem a Erik Jayme, Rio de Janeiro, Editota Renovar, 2005, pp. 141 e seguintes.

19 Id.

2 Id.

21 Id.

22 Id. 
é o que caracteriza os negócios nos dias de hoje, poderia-se argumentar que a conexão pela residência do proponente não seja suficientemente adequada. Primeiro, porque a residência pode ser facilmente utilizada de forma fraudulenta para a incidência de um determinado direito que nada tem a ver com a relação contratual, resultando apenas do acaso de ali ter o proponente firmado sua última residência. Em segundo lugar, se a mobilidade dos negócios é realmente o motif da escolha do legislador da LICC de 1942, então por que não optar logo pelo elemento de conexão autonomia da vontade? Tal opção tornaria as contratações businessto business mais transparentes e menos onerosas para estes parceiros que não precisariam mais firmar residência em foros percebidos de um direito mais favorável aos seus interesses.

Em linhas gerais, conclui-se que a lei tal como está (lex lata) cria um ambiente de imprevisibilidade e insegurança jurídica e que o direito como deve ser (lex ferenda) deve superar as limitações do atual quadro normativo para -incluir a autonomia da vontade (limitada em alguns casos) como elemento de conexão em matéria obrigacional. Note-se que o elemento de conexão autonomia da vontade foi revivido pela CIDIP V (Cidade do México, 1994), por meio da Convenção Interamericana sobre a Lei Aplicável aos Contratos Internacionais, assinada pelo Brasil, mas ainda não ratificada.

\section{O Contrato de Arbitragem Comercial}

A conceituação da arbitragem comercial não é pacífica. Existem, pelo menos, duas grandes escolas de arbitragem comercial. A primeira delas, de origem continental européia releva o caráter institucional da arbitragem, estando esta em semelhança à autoridade judiciária estatal. Já a escola norte-americana prefere uma classificação contratual da arbitragem, chegando a dizer que ela é "o sonho das partes" (Le rêve des parties) ${ }^{23}$, pois nela as partes tudo podem e o único limite é a imaginação dos contratantes:

"Celles-ci [des parties] sont libres, comme la Cour Suprême [des États-Unis] l'a écrit dans l'arrêt Volt, 'de structurer les conventions d'arbitrage comme elles l'entendent. Elles peuvent limiter l'objet du litige qui relèvera de la compétence de l'arbitrage ainsi que préciser les règles de droit qui gouverneront l'arbitrage'. Elles sont donc libres de choisir le type de questions litigieuses qui seront soumises ou non à l'arbitrage; ainsi de destinguer, par exemple, entre les litiges portant sur le créances échues et ceux portant sur les créances à échoir dans un contrat de distribuition, ou encore entre les litiges relatifs aux violations présumées du droit d'auteur et ceux qui se rapportent au droit des marques. Les parties peuvent également renverser le principe selon lequel l'arbitre est compétent pour décider de la validité au fond du contrat duqel découle sa compétence."24

Pelo aspecto contratual da arbitragem, as partes têm uma liberdade de contratar quase sem limites em princípio. Portanto, compete às partes, em uma arbitragem, disporem sobre a competência arbitral para decidir acerca da validade e existência do acordo arbitral,

23 HART, Henry M. Jx \& SACKS, Albert M., The Legal Process: Basic Problems in the Making and Application of Law; Foundation Press, 1994 , p. 310, Apud RAU, Alan Scott \& PÉDAMON, Catherine, La Contratualisation de L'Arbitrage: Le Modèle Américain, Revue de L'Arbitrage 2001 -N. 3, p. 458

24 RAU \& PÉDAMON, Revue de L'Arbitrage $2001-$ N. 3, p. 458 
aqui compreendida a extensão da própria competência dos árbitros (competênciacompetência) e decidir sobre os tipos de disputas passíveis de arbitragem (arbitrabilidade). Ainda, outra peculiaridade contratual da arbitragem é a existência autônoma da convenção arbitral com relação ao contrato ao qual ela está inserta (separabilidade).

Esses três institutos: competência-competência, separabilidade e arbitrabilidade evidenciam o caráter contratual da arbitragem, razão pela qual explorarei cada um deles mais detalhadamente para comprovar minha tese de que a arbitragem, na esfera internacional, é modalidade de contrato internacional (Parte 1). Se arbitragem internacional é contrato, segundo o direito brasileiro, ela deveria estar sujeita às regras conflituais do artigo 9 da LICC. Entretanto, o que demonstrarei é que mesmo sendo um contrato internacional, que em princípio sujeitaria-se às limitações do artigo 9 da LICC, ela vem em verdade se sobrepondo àquelas regras, funcionando como um elemento de renovação do DIPr brasileiro dos contratos (Parte 2).

\section{A Contratualização da Arbitragem Comercial em Evidência}

\section{i. Competência-competência}

$O$ instituto da competência-competência se traduz principalmente na questão a quem compete decidir sobre a competência do tribunal arbitral: aos árbitros ou à autoridade judiciária estatal? As legislações mais modernas em matéria de arbitragem dispõem sobre essa questão, sendo unânime a conclusão no sentido de que essa competência recai sobre o tribunal arbitral. ${ }^{25}$ A justificativa é de natureza contratual, isto é, já que as partes submeteram a disputa à arbitragem, é natural que a própria questão sobre a quem compete decidir sobre a competência do tribunal arbitral também recaia aos árbitros designados. $\mathrm{E}$ também em razão da natureza contratual da arbitragem é que se pode concluir que apenas não caberá ao tribunal arbitral decidir sobre a sua

25 Veja artigo 16(1) da Lei Modelo da United Nations Commission for International Trade Law (UNCITRAL) sobre Arbitragem Comercial Intemacional de 21.06.1985: "O tribunal arbitral pode decidir sobre sua própria competência, aí incluída qualquer exceção relativa à existência ou à validade da convenção de arbitragem." Veja tambémattigo 6(2) do Regulamento de Arbitragem da Corte Internacional de Arbitragem da Câmara de Comércio Internacional (CCI): "Se o requerido não apresentar a sua defesa, de acordo com o estabelecido no artigo 5, ou se uma das partes formular uma ou mais exceções quanto à existência, validade, ou escopo da convençao de arbitragem, a Corte poderá decidir, sem prejuizo da admissibilidade da exceção ou das exceções, que a arbitragem poderá prosseguir se estiver convencida, prima facie, da possível existência de uma convenção de arbitragem conforme o Regulamento. Neste caso, qualquer decisão quanto à jurisdição do Tribunal Arbitral deverá ser tomada pelo próprio tribunal. Se a Corte não estiver convencida dessa possivel existência, as partes seräo notificadas de que a arbitragem não poderá prosseguir. Neste caso, as partes conservam o direito de solicitar uma decisão de qualquer tribural competente sobre a existência ou não se uma convenção de arbitragem que as obrigue." Da mesma forma, a Lei 9.307 de 23 de setembro de 1996, no parágrafo único do artigo 8 dispõe: "Caberá ao árbitro decidir de ofício, ou por provocação das partes, as questões acerca da existência, validade e eficácia da convenção de arbitragem e do contrato que contenha a cláusula compromissória." 
própria competência quando assim pactuarem as partes. A default rule é clara: no silêncio das partes, o tribunal arbitral decide sobre sua própria competência.

O termo competência-competência, porém, varia na sua aplicação dependendo do sistema legal que o aplica. ${ }^{26}$ Assim tem-se em primeiro lugar o modelo inglês do instituto, que no original em inglês leva o nome de jurisdiction to decide jurisdiction ou simplesmente comptence-comptence. Segundo este modelo, o tribunal arbitral pode decidir acerca da sua própria competência, sem esperar que a autoridade judiciária estatal o faça. ${ }^{27}$ Entetanto, a decisão dos árbitros a respeito de sua competência estará sujeita a revisão judicial a qualquer momento. ${ }^{28}$

De acordo com o modelo francês de competência-competência (compétencecompétence), por força do artigo 1458 do Novo Código de Processo Civil Francês ${ }^{29}$, os árbitros decidem acerca de sua competência de maneira preliminar, sujeita à revisão judicial, uma vez concluída a arbitragem. ${ }^{30}$ No Brasil, em sentido semelhante posicionou-se o Poder Judiciário do Estado do Rio de Janeiro ${ }^{31}$.

Um terceiro modelo de Kompetenz-Kompetenz seria o do direito alemão, segundo o qual o tribunal arbitral decide sobre sua própria competência de forma definitiva, isto é, sem revisão judicial por parte da autoridade judiciária. ${ }^{32} \bigcirc$ conceito foi discutido numa decisão do Bundensgerichtshof envolvendo uma série de relações complicadas oriundas de um contrato de transporte. Neste caso, a Corte admitiu a possibilidade de um acordo sobre jurisdição (eine Kompeten₹-Kompeten₹-Klause) que daria ao tribunal arbitral poder para decidir definitivamente acerca de sua competência, mas deixou para a corte de apelação imediatamente inferior a difícil tarefa de decidir se, de fato, aquela cláusula no contrato de transporte existia e se vinculava a parte que resistia à arbitragem. ${ }^{33}$

Nos Estados Unidos, o leading case na matéria é First Options of Chicago, Inc. $v$.

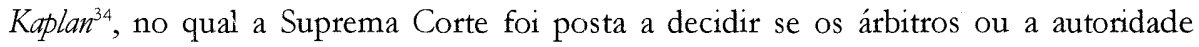

26 PARK, William W., The Arbitrability Dicta in First Option V Kaplan: What Sort of Kompetenz-Kompetenz Has Crossed the Atiantic?, Mealey's Intemational Arbitration Reports, October 1996.

$27 \mathrm{Id}$.

28 Id.

22 Article 1458 du Noveau Code de Procedure Civile:

Lorsqu'un litige dont un tribunal arbitral est saisi en vertu d'une convention d'arbitrage est porté devant une juridiction de l'Etat, celle-ci doit se déclarer incompétente.

Si le tribunal arbitral n'est pas encore saisi, la juridiction doit également se déclarer incompétente à moins que la convention d'arbitrage ne soit manifestement nulle.

Dans les deux cas, la juridictioni ne peut relever d'office son incompétence.

30 PARKER, supranota 26

31 Foro Regional da Barra da Tijuca, Júzo de Direito da 2 Vara Cível, Processo No. 2004.209.003666-3. Juiz Carlos Fernando Potyguara Pereira (J. 14.06.2005): "Em nosso ordenamento jurídico, o instituto da arbitragem é regulado pela Lei no. 9.307/ 96. De acordo com esse diploma legal, ao árbitro escolhido pelas partes compete primeiramente se pronunciar sobre a existência, validade, e eficácia da convenção de arbitragem (parágrafo único do artigo 8). Sendo assim, não cabe ao Poder Judiciário se pronunciar sobre tal questão antes de prolatada a sentença arbitral. $\mathrm{Na}$ verdade, segundo a Lei de Arbitragem, cabe ao Judiciário, posteriormente, apreciar tal tema somente após a prolação da sentença arbitral, se provocado por meio de ação própria verificar e, eventualmente, decretar a sua nulidade (artigo $32 \mathrm{c} / \mathrm{c} 33$ )": P. 2.

2 PARKER, supra nota 26

33 Id.

34 First Options of Chicago, Inc. 2: Kaplan, 514 U.S. 938 (1995). 
judiciária estatal tem competência primária para decidir se as partes de uma arbitragem acordaram em arbitrar o mérito da disputa.

O caso surgiu da controvérsia acerca de um "workout agreement", consubstanciado em quatro documentos, que disciplinam a resolução (working out) de dívidas devidas pelo réu Manuel Kaplan, sua esposa, e sua empresa de investimentos $M K$ Investment, Inc. (MKI), à empresa autora, First Options of Chicago, Inc., uma empresa que salda ações (clear stock trades) na Bolsa de Valores da Filadélfia. Para MKI, First Options se encarregou de assumir controle, e liquidar, alguns de seus bens. ${ }^{35}$

Quando Firts Options demandou o pagamento e não obteve êxito, a empresa recorreu à arbitragem naquela Bolsa de Valores. $M K I$, que havia assinado o único acordo contendo uma convenção de arbitragem submeteu-se ao procedimento arbitral, mas os Kaplans, que não haviam assinado essa convenção, questionaram a competência da autoridade arbitral sobre eles e negaram que a controvérsia com a empresa First Options era arbitrável.

Os árbitros decidiram que eles tinham competência para julgar o mérito da controvérsia, posicionando-se em favor de First Options. A Corte de Primeira Instância (District Court) confirmou a decisão arbitral, mas o Tribunal de Segunda Instância (Court of Appeals) rejeitou tal entendimento. Ao firmar posicionamento que a controvérsia não era arbitrável, o Tribunal de Segunda Instância decidiu que caberia às cortes estatais julgar se os árbitros têm competência sobre a controvérsia.

$\bigcirc$ fundamento do Tribunal de Segunda Instância é contratual. Em outras palavras, o Tribunal afirmou que assim como a arbitrabilidade do mérito da controvérsia depende das partes terem acordado arbitrar a controvérsia ${ }^{36}$, a questão sobre a quem compete decidir sobre a arbitrabilidade da disputa também depende de acordo das partes em submeter essa pergunta aos árbitros. ${ }^{37}$ Caso as partes acordaram submeter essa questão aos árbitros, a autoridade estatal deve declinar de sua competência e acatar a da autoridade arbitral. Mas, se não há evidências suficientes que permitam concluir que as partes tiveram a intenção de delegar aos árbitros a competência para julgar se a controvérsia é mesmo arbitrável, então deve a autoridade estatal decidir. ${ }^{38}$ No presente caso, o Tribunal de Segunda Instância constatou que os Kaplans não acordaram arbitrar arbitrabilidade, o que envia essa questão à competência da autoridade judiciária estatal. ${ }^{39}$

A Suprema Corte dos Estados Unidos foi chamada a opinar sobre duas questões relativas ao caso First Options of Chicago, Inc. v. Kaplan, quais sejam: 1) como uma corte de primeira instância deve revisar a decisão da autoridade arbitral onde as partes acordaram arbitrar uma disputa, e 2) como um tribunal de segunda instância deve revisar a decisão da corte de primeira instância que confirma ou recusa a nulidade de

\footnotetext{
35 Id., p. 940

36 Veja Mastrobuono t: Sbearson Lebman Hutton, Inc, 514 U.S. 52 (1995).

37 First Options of Chicago, Inc. 2: Kaplan, 514 U.S. 938 (1995).

${ }^{38} \mathrm{Id}$.

${ }^{39}$ Id, p. 939
} 
uma sentença arbitral. Tudo mais constante da parte dispositiva da decisão da Suprema Corte que não diz respeito diretamente a essas duas questões é dictum.

Este artigo, por sua vez, enfoca na lógica jurídica aplicada pelo Ministro Breyer, que responde em nome da Suprema Corte dos Estados Unidos. Esta lógica é de natureza contratual, o que confirma a tese da arbitragem comercial como contrato. Como explica o Ministro Breyer, três tipos de desavenças marcam o presente caso ${ }^{40}$. Primeiro, os Kaplans e Firts Options discordam se aqueles são pessoalmente responsáveis pela dívida de $M K I$ com First Options. Esta desavença diz respeito ao mérito da disputa ${ }^{41}$. Segundo, eles discordam se houve realmente um acordo para arbitrar o mérito da disputa ${ }^{42}$. Terceiro, não há consenso sobre quem tem competência primária para decidir a segunda desavença $a^{43}$. A Corte centra-se na terceira desavença, is to é, a quem compete decidir primariamente se as partes acordaram arbitrar o mérito da disputa: aos árbitros ou à autoridade judiciária estatal?

A conseqüência prática da questão é evidente e decorre inexoravelmente do fato da arbitragem ser um contrato entre as partes. Assim, se, por exemplo, uma das partes não acordou arbitrar a disputa, essa mesma parte terá o direito de recorrer à autoridade judiciária para decidir acerca do mérito da disputa ${ }^{44}$. Agora, se houve acordo para arbitrar o mérito da disputa $^{45}$, essa parte abdicou daquele direito, e a autoridade judiciária só poderá se manifestar, se provocada, para reverter a decisão arbitral nas circunstâncias elencadas no Artigo $10^{46}$.

Já que a arbitragem é um contrato, a Suprema Corte recorreu às regras de formação dos contratos para responder a questão acerca da competência para decidir se houve acordo de vontade entre First Options e os Kaplans no que concerne à arbitragem do mérito da disputa.

40 Id. p. 942

${ }^{41} \mathrm{Id}$.

${ }^{42} \mathrm{Id}$.

43 First Options of Chicago, Inc. v. Kaplan, 514 U.S. 938, 942 (1995).

${ }^{44} \mathrm{Id}$.

45 Veja AT \& T Technologies, Inc. 2: Communications Workers, 475 U.S. 643, 649 (1986) e Steelworkers 2: Warrior or Gulf Nar: Co., 363 U.S. 574,583 (1960) (ambos julgados entendendo que a arbitrabilidade da disputa é arbitrável).

46 Federal Arbitration Act, Section 10. Same; vacation; grounds; rehearing

(a) In any of the following cases the United States court in and for the district wherein the award was made may make an order vacating the award upon the application of any party to the arbitration

(1) Where the award was procured by corruption, fraud, or undue means.

(2) Where there was evident partiality or corruption in the arbitrators, or either of them.

(3) Where the arbitrators were guilty of misconduct in refusing to postpone the hearing, upon sufficient cause shown, or in refusing to hear evidence pertinent and material to the controversy; or of any other misbehavior by which the rights of any party have been prejudiced

(4) Where the arbitrators exceeded their powers, or so imperfectly executed them that a mutual, final, and definite award upon the subject matter submitted was not made.

(5) Where an award is vacated and the time within which the agreement required the award to be made has not expired the court may, in its discretion, direct a rehearing by the arbitrators.

(b) The United States district court for the district wherein an award was made that was issued pursuant to section 590 of title 5 may make an order vacating the award upon the application of a person, other than a party to the arbitration, who is adversely affected or aggrieved by the award, if the use of arbitration or the award is clearly inconsistent with the factors set forth in section 582 of Title 5 . 
O direito contratual requer que haja provas de um acordo de vontade (meeting of the minds) entre First Options e os Kaplans, no qual esses, voluntariamente, delegavam aos árbitros a competência para decidir se as partes acordaram arbitrar o mérito. Só assim poderiam os Kaplans estar sujeitos à competência arbitral. Neste ponto, a Suprema Corte chama a atenção para uma distinção tênue, mas importante, que diferencia entre a questão a quem compete decidir sobre a arbitrabilidade da disputa (who) daquela sobre o que é arbitrável na controvérsia (whether $)^{48}$

Com relação à primeira questão, a Corte invoca um precedente da jurisprudência americana que afirma que "Courts should not assume that the parties agreed to arbitrate arbitrability unless there is clear and unmistakable evidence that they did so" "49. Mas essa presunção é revertida, como esclarece a Suprema Corte ${ }^{50}$, com relação à segunda questão. Assim, "any doubts concerning the scope of arbitrable issues should be resolved in favor of arbitration" ${ }^{\prime \prime 2}$.

A justificativa para a diferenciação entre a questão a quem compete decidir sobre a arbitrabilidade da disputa daquela sobre o que é arbitrável na controvérsia é simples ${ }^{52} . \mathrm{Na}$ segunda delas, assume-se que as partes já tenham pensado na arbitragem e a questão seria um segundo passo, relacionada à extensão da convenção arbitral. Já a primeira questão é anterior a isso, ou seja, busca-se definir a quem compete decidir sobre a arbitrabilidade da disputa. Neste caso, a existência da competência arbitral ainda não é manifestamente evidente.

Assim, a Suprema Corte ponderadamente conclui que "given the principle that a party can be forced to arbitrate only those issues it speciffically has agreed to submit to arbitration, one can understand why courts might hesitate to interpret silence or ambiguity on the 'who should decide arbitrability' point as giving the arbitrators that power, for doing so might too often force unwilling parties to arbitrate a matter they reasonably would have thought a judge, not an arbitrator, would decide's3. Na inexistência da manifestação de vontade dos Kaplans em delegar a questão sobre quem deve decidir a arbitrabilidade da disputa aos árbitros, a Suprema Corte confirma a decisão do Tribunal de Segunda Instância, que concluiu pela competência da autoridade judiciária ${ }^{54}$.

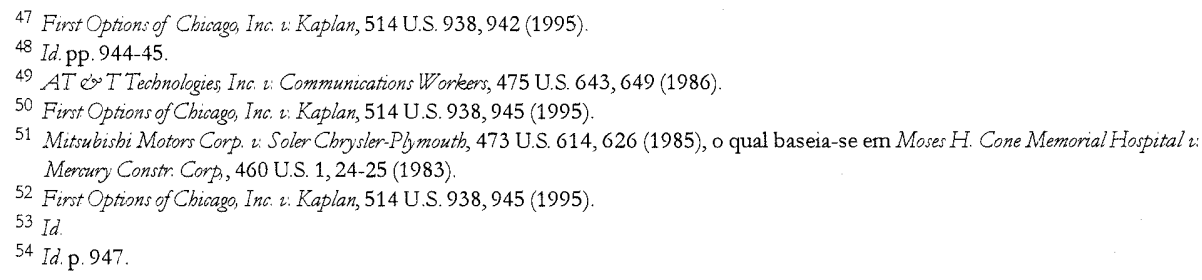




\section{ii. Separabilidade}

O instituto da separabilidade, ou da autonomia da cláusula compromissória, sustenta que a cláusula compromissória é independente do contrato no qual ela está inserta. As implicações provenientes desse instituto são renovadoras, pois em nenhum outro tipo de contrato que se tenha notícia uma cláusula contratual pode restar válida depois que o contrato que a abriga é considerado nulo. A arbitrabilidade é reconhecida nas principais legislações de arbitragem $^{55}$.

Nos Estados Unidos, o leading case em matéria de separabilidade é o caso Prima Paint v. Flood \& Conklin ${ }^{56}$. A questão posta à apreciação da Suprema Corte foi em saber se a acusação de um contrato induzido em fraude deve ser resolvida por autoridade judiciária ou por autoridade arbitral, por força de cláusula compromissória constante do contrato.

A disputa tem origem nos fatos que seguem. Prima Paint, empresa do Estado de Maryland, comprou o segmento de tintas de Flood \& Conklin, empresa do Estado de Nova Jersey. Três semanas depois, as duas empresas acertaram um contrato de prestação de consultoria, onde Flood \& Conklin, por um periodo de seis anos, atenderia Prima Paint em dúvidas relativas à formulação, produção, operação e vendas no recém adquirido segmento de tintas. $O$ contrato previa que esses serviços seriam prestados pessoalmente pelo Diretor da empresa Flood \& Conklin. Flood \& Conklin se comprometeu a não competir com Prima Paint, passando-lhe, inclusive, a lista de clientes que, a partir de então, seriam assumidos pela empresa compradora.

Em troca, Prima Paint acordou pagar Flood \& Conklin um certo percentual da receita oriunda desses consumidores e sobre demais vendas, não excedendo U\$225.000 durante todo período de duração da prestação de serviços. Finalmente, as partes acordaram numa cláusula de arbitragem nos seguintes termos:

"Any controversy or claim out of or relating to this Agreement, or the breach thereof, shall be settled by arbitration in the City of New York, in accordance with the rules then pertaining of the American Arbitration Association."

\footnotetext{
55 Veja o artigo 16 (1) da Lei Modelo de Arbitragem da UNCITRAL sobre Arbitragem Comercial Internacional de 21.06.1985: “(...) uma cláusula compromissória que faça parte de um contrato é considerada como uma convenção distinta das outras cláusulas do contrato. A decisão do tribunal arbitral que considere nulo o contrato não implica automaticamente a nulidade da cláusula compromissória." Veja também artigo 6(4) do Regulamento da Corte Internacional de Arbitragem da CCI: "Salvo estipulação em contrário, e sempre que tenha admitido a validade da convenção de arbitragem, o Tribunal Arbitral não deixará de ser competente em razão de pretensa nulidade ou inexistência do contrato. O Tribunal Arbitral continuará a ter jurisdição para determinar os respectivos direitos das partes e para julgar as suas reinvindicações e alegações". Da mesma forma, o artigo 8 da Lei 9.307 de 23 de setembro de 1996 dispõe: "A cláusula compromissória é autônoma em relação ao contrato em que estiver inserta, de tal sorte que a nulidade deste não implica, necessariamente, a nulidade da cláusula compromissória."

56 Prima Paint 2: Flood \& Conkin, 388 U.S. 395 (1967).
} 
Na ocasião do primeiro pagamento relativo à prestação de serviços, Prima Paint notificou Flood \& Conklin do seu descontentamento, alegando que esta havia fraudulosamente representado-se como solvente e capaz de cumprir com suas obrigações contratuais, quando, na verdade, estava insolvente e que havia entrado com pedido de concordata, nos termos do Capítulo XI da Lei de Falências americana, logo depois de celebrar o contrato de consultoria.

Flood \& Conklin respondeu notificando sua intenção de levar a disputa à arbitragem. Dias antes de expirar o prazo de resposta de Prima Paint, esta ingressou em juízo na Corte de Primeira Instância de Nova York, requerendo a rescisão do contrato de consultoria com base em indução em fraude para contratar. Concomitantemente, Prima Paint requereu que a referida Corte emitisse uma ordem à Flood \& Conklin, impedindo a arbitragem da disputa.

Flood \& Conklin, em resposta, requereu a paralisação dos procedimentos judiciais enquanto se processava a arbitragem. Por fim, alegou. que a questão sobre a indução em fraude para contratar deve ser decidida pelos árbitros e não por uma corte estatal.

A Corte de Primeira Instância de Nova York acolheu o pedido de Flood \& Conklin de paralisação dos procedimentos judiciais enquanto se processava a arbitragem, decidindo que a acusação de indução em fraude em um contrato contendo cláusula arbitral é matéria para ser decidida pela autoridade arbitral. ${ }^{57} \mathrm{O}$ Tribunal de Segunda Instância confirmou que esse entendimento deve prevalecer, ${ }^{58}$ em razão da separabilidade da cláusula arbitral ${ }^{59}$.

O Ministro Fortas emitiu a opinião da Suprema Corte dos Estados Unidos, acolhendo a tese da separabilidade da cláusula arbitral no presente caso e acrescentando que decisão diferente se chegaria caso a acusação de indução em fraude fosse referente à cláusula arbitral em si, e não do contrato como um todo. ${ }^{60}$

Já com relação à questões sobre a validade da cláusula arbitral, em dictum, a Suprema Corte afirma que estas podem ser (may) decididas por uma corte estatal ${ }^{61}$. (Grifo meu). Note-se, entretanto, que a linguagem da Suprema Corte deixa margem para se argumentar que a competência dos árbitros não está de todo excluída. Para justificar a maior cautela com a cláusula arbitral, a Corte explica que: "To immunize an arbitration agreement from judicial challenge on ground of fraud in the inducement would be to elevate it over other forms of contract's2.

\footnotetext{
57 Id. p. 399 . Veja Robert Laurene Co. 2: Devonshire Fabrios, Inc, 271 F.2d 402 (C.A.2d Cir. 1959).

58 Prima Paint r. Flood \& Conkin, 388 U.S. 395, 399 (1967).

${ }^{59}$ Id. p. 402

${ }^{60}$ Mas veja voto dissidente do Ministro Black, acompahado pelos Ministros Douglas e Stewart: "If the contract was procured by fraud, then, unless the defrauded party elects to affirm it, there is absolutely no contract, nothing to be arbitrated." Id, p.412.

61 Id. pp 403-04 ("Acoordingly, if the claim is fraud in the inducement of the arbitration clause itself - an issue wibich goes to the 'making' of the agreement to arbitrate - the federal court may proceed to adjudicate it'.) Veja Moseley z: Electronic or Missile Facilities, 374 U.S. 167, 171, 172, 83 S.Ct. 1815, 1817, 1818, 10 L.Ed 2d 818 (1963). Veja também artigo 4 do Lei Federal de Arbitragem Americana: “(...) The court shall bear the parties, and' upon being satisfied that the making of the agreement for arbitration or the failure to comply thenemith is not in issue, the court shall make an order directing the parties to proceed to arbitration in accordance with the terms of the agreement (...) If the making of the arbitration agreement or the failure, neglect, or refusal to perform the same be in issue, the court shall proceed summarily to the trial thereof. (...)"

62 Prima Paint r: Flood er Conkin, 388 U.S. 395, 404 n. 12 (1967).
} 
Por derradeiro, a Suprema Corte conclui que a decisão do Tribunal de Segunda Instância que não conhece da apelação de Prima Paint deve ser confirmada, pois: 1) a acusação de indução em fraude é relativa ao contrato e não à cláusula arbitral inserta nesse contrato ${ }^{63}$, e 2) Prima Paint em nenhum momento demonstrou sua intenção para que questões juridicas relacionadas ao contrato fossem excluídas da arbitragem ${ }^{64}$.

\section{iii. Arbitrabilidade}

"A arbitrabilidade é a aptidão de um litígio ser objeto de um arbitragem" Há quem distinga a arbitrabilidade subjetiva da objetiva. A arbitrabilidade subjetiva "refere-se à possibilidade de um Estado ou de uma entidade pública celebrar uma convenção de arbitragem" ${ }^{196}$, também conhecida com $\Theta$ arbitrabilidade ratione persona $e^{67}$. A arbitrabilidade objetiva está relacionada ao objeto do litígio, a arbitrabilidade ratione materiae ${ }^{68}$. Penso que o âmago do instituto da arbitrabilidade está no que se conceitua arbitrabilidade objetiva, estando a categoria subjetiva relacionada com a questão da capacidade do ente para celebrar uma arbitragem, um requisito comum à forma dos contratos.

Se por um lado algumas legislações sobre arbitragem são bastante precisas em delimitar a matéria suscetível à arbitragem ${ }^{69}$, outras deixam maior espaço para interpretação das cortes sobre os limites da arbitrabilidade. ${ }^{70}$

O caso que abordo a seguir, Mitsubishi Motors Corp. v. Soler Chrysler-Plymouth ${ }^{71}$, ilustra bem as dificuldades encontradas pela Suprema Corte dos Estados Unidos para pontuar os limites da arbitrabilidade, em face do texto abrangente do legislador americano. Em suma, o caso retrata o esforço daquela corte em promover uma política liberal de arbitragem, mesmo em sede de direito público. Para aqueles que apreciam a discussão da privatização do direito público, eis um exemplo proeminente da contratualização do direito da concorrência via arbitragem.

Em Mitsubishi Motors Corp. v. Soler Chrysler-Plymouth, a Suprema Corte dos Estados Unidos foi consultada sobre a possibilidade de submeter à arbitragem comercial internacional disputas relativas ao direito da concorrência americano.

\footnotetext{
63 Id. p. 405

$64 \mathrm{Id}$.

65 Veja Bénédicte Fauvarque-Cosson, Libre Disponibilité des Droits et Conflits de lois, prefácio de Y. Lequette, Paris, LGDJ, 1996, p. 94 , Apud Lee, João Bosco, Arbitragem Comercial Internacional nos Países do Mercosul, 4. ed. Curitiba: Editora Juruá, 2005. p. 51 .

${ }^{66}$ Lee, João Bosco, Arbitragem Comercial Internacional, supra nota 61, pp. 51-52.

${ }^{67}$ Id. p. 52.

$68 \mathrm{Id}$.

69 Veja artigo 1 da Lei 9.307 , de 23 de setembro de 1996: “As pessoas capazes de contratar poderão valer-se da arbitragem para dirimir litígios relativos a direitos patrimoniais disponíveis".

70 Artigo 2 da Lei Federal de Arbitragem Americana: "A written provision in any maritime transaction or a contract evidencing a transaction involving commerce (...) or an agreement in writing to submit to arbitration an existing controversy arising out of such a contract[]"

71 Mitsubishi Motors Corp. 2: Soler Chrysler-Plymowib, 473 U.S. 614 (1985).
} 
A autora é Mitsubishi Motors Corp., empresa japonesa produto de uma joint venture entre Chrysler International, S.A. (CISA) (empresa suíça) e Mitsubishi Heary Industries, Inc. (empresa japonesa). A joint venture visa a distribuir automóveis produzidos por Mitsubishi para fora dos Estados Unidos (continental) através de concessionárias Chrysler. A ré Soler Chrysler-Plymouth, Inc., empresa porto-riquenha, firmou contrato de distribuição com CISA dos automóveis Mitsubishi dentro de uma área demarcada, que incluía a região metropolitana de San Juan. Na mesma ocasião, CISA, Soler e Mitsubishi formaram um contrato de vendas, o qual, referindo-se ao contrato de distribuição, disciplinava a venda direta de automóveis Mitsubishi por Soler, bem como os termos e as condições das vendas. $O$ contrato de vendas continha a seguinte cláusula arbitral:

"All disputes, controversies or differences which-may arise between [Mitsubishi] and [Soler] out of or in relation to Articles I-B through $V$ of this Agreement or for the breach thereof, shall be finally settled by arbitration in Japan in accordance with the rules and regulations of the Japan Commercial Arbitration Association"72.

No decurso da execução do contrato, Soler incorreu em dificuldades para atender ao volume de vendas dos automóveis da autora, o que a fez requerer que Mitsubishi atrasasse ou cancelasse a entrega de vários pedidos. Ao mesmo tempo, Soler tentou criar uma operação pela qual redirecionaria os veículos Mitsubishi para os Estados Unidos (continental) e América Latina. Mitsubishi e CISA, entretanto, rejeitaram as propostas de Soler. Outras tentativas de superar as dificuldades de Soler não obtiveram sucesso, e Mitsubishi acabou retendo a entrega de 966 veículos para a empresa ré.

Em seguida, Mitsubishi acionou Soler na Corte de Primeira Instância dos Estados Unidos, em Porto Rico, com fundamento na Lei Federal de Arbitragem americana e na Convenção sobre Reconhecimento e Execução de Sentenças Estrangeiras de Nova York ${ }^{73}$. Nesta ação, Mitsubishi pleiteava uma ordem para compelir às partes a arbitrarem a disputa, conforme cláusula arbitral constante do contrato de vendas. Logo após, Mitsubishi requereu início de procedimentos arbitrais junto à Associação de Arbitragem Comercial do Japão ${ }^{74}$.

Soler rejeitou a argumentação de CISA e Mitsubishi e contra-argumentou, apontando para incumprimento por parte de Mitsubishi de diversas obrigações assumidas no contrato de vendas, e, mais importante, inobservância do direito da concorrência presente no Sherman $A c t^{5}$, alegando conspiração entre CISA e Mitsubishi para dividir o mercado de forma a restringir o comércio ${ }^{76}$.

\footnotetext{
${ }^{72}$ Id. p. 617.

${ }^{73}$ Id. p. 618

74 Id.

75 O Sherman Antitrust. Act é o estatuto federal em vigor desde 1890 que visa proibir restrição nầ razoável e monopolização de comércio interestadual ou internacional O estatuto proíbe duas ou mais pessoas de se engajarem em práticas monopolísticas e frxação de preço.

${ }^{76}$ Mitsubishi Motors Corp. i: Soler Cbrysler-Plymouth, 473 U.S. 614, 619-620 (1985)
} 
A Corte de Primeira Instância mandou que Mitsubishi e Soler arbitrassem a disputa, inclusive as questões de direito da concorrência ${ }^{77}$. O Tribunal de Segunda Instância confirmou a decisão da corte inferior, mas rejeitou a arbitrabilidade das questões de direito da concorrência ${ }^{78}$.

A disputa foi então levada à Suprema Corte dos Estados Unidos para que esta se posicionasse acerca da possibilidade de submeter à arbitragem comercial internacional disputas relativas ao direito da concorrência americano. $\mathrm{O}$ Ministro relator Blackmun dividiu sua análise em duas partes: 1) se a cláusula arbitral engloba as questões de direito da concorrência ${ }^{79}$, e 2) se essas questões de direito da concorrência estão sujeitas à arbitragem, mesmo que as partes tenham assim convencionado ${ }^{80}$.

Com relação à primeira questão, a Suprema Corte retoma o argumento de Soler, onde alega que a apreciação de questões de direito da concorrência só poderia ocorrer em sede de arbitragem se as partes houvessem convencionado ${ }^{81}$. Nesta linha de argumentação de Soler, o silêncio das partes a respeito do direito da concorrência eventualmente relacionado ao contrato não deveria ser interpretado como permissivo de arbitragem dessas questões.

A Suprema Corte rejeita a argumentação apresentada por Soler, pois não encontra fundamento na Lei Federal de Arbitragem americana que sustente a presunção de nãoarbitrabilidade de questões de direito da concorrência. Aqui, a Suprema Corte mais uma vez relembra que a arbitragem é um contrato, e a Lei de Arbitragem apenas cria um corpo de regras substantivas para disciplinar e regular o dever de honrar com a arbitragem ${ }^{82}$. E mais, que a preocupação primordial do Congresso americano em aprovar a Lei de Arbitragem foi para garantir o cumprimento de acordos privados aos quais as partes se submeteram ${ }^{83}$.

Em assim sendo, o primeiro passo a ser tomado pela corte que analisa essa questão, é perquerir se houve acordo das partes com relação à arbitragem de questões concorrenciais, lembrando que a interpretação deve favorecer a arbitrabilidade das disputas ${ }^{84}$.

Em se tratando do envolvimento de questões relativas à direito concorrencial, a Suprema Corte não vê motivos para conferir interpretação diversa das demais ${ }^{85}$, sem que tal posicionamento implique que todas as disputas que envolvam direitos oriundos de estatutos (statutory rights), a exemplo da proteção da concorrência, sejam arbitráveis ${ }^{86}$.

\footnotetext{
77 Id. p 620. Neste ponto, a Corte de Primeira Instância reconheceu a regta de American Safety Equipment Corp. 2: JP. Maguire \&ُ Co., 391 F.2d 821 (CA2 1968) (assegurando que os direitos conferidos pelas leis de concorrência são inapropriados para execução através de arbitragem), mas se baseou em Scherk v. Albetto-Culver Co., 417 U.S. 506, 515-520, 94 S.Ct. 2449, 2455-2458, 41 L.Ed.2d 270 (1974) (onde uma corte mandou que se arbitrasse uma disputa proveniente de um contrato internacional, com fundamento no Securities Exchange Act americano.)

78 Mitsubishi Motors Corp. 2: Soler Chrysler-Plymouth, 473 U.S. 614, 623 (1985).

${ }^{79}$ Id. pp. 624 e seguintes.

${ }^{80}$ Id. pp. 628 e seguintes

81 Id. pp. 624-625.

82 Veja Moses H. Cone Memorial Hospital 2: Mercury Construction Corp, 460 U.S. 1, 24, 103 S.Ct. 927, 941, 74 L.Ed.2d. 765 (1983).

83 Dean Witter Reynolds Inc. 2: Byrd, 470 U.S. 213, 221, 105 S.Ct. 1238, 1242, 84 L.Ed.2d 158 (1985).

84 "QRJuestions of arbitrability must be addressed with a bealtby regard for the federal polioy faroring arbitration (...)." Moses $H$. Cone Memorial Hospital 2: Merrury Construction, 460 U.S., pp. 24-25, 103 S.Ct., pp. 941-942.

85 Mitsubishi Motors Corp. i: Soler Chrysler-Plymouth, 473 U.S. 614, 626 (1985).

86 Id. p. 627.
} 
Para a Suprema Corte, ao contrário do que argumenta Soler, permitir que direitos oriundos de estatutos tal como o Sherman Act, que trata da concorrência, sejam apreciados em sede arbitral não significa que as partes não terão os direitos assegurados pelos estatutos ${ }^{87}$. A única mudança, adverte a Suprema Corte, é que ao invés de serem apreciados por uma autoridade judiciária, eles o serão por uma instituição arbitral ${ }^{88}$.

No presente caso, a Suprema Corte não encontrou evidências das partes expressando sua vontade em não submeter questões relativas à direito concorrencial à arbitragem, razão pela qual a Corte presume uma manifestação de vontade das partes em favor da arbitragem.

Com relação à segunda parte da análise do Ministro Blackmun, isto é, sobre a arbitrabilidade de questões de direito da concorrência convencionada pelas partes, diferentemente do Tribunal de Segunda Instância ${ }^{89}$, decidiu-se que direito da concorrência pode ser apreciado em sede de arbitragem. Acompanhando o direito extraído do caso Sherck v. Alberto-Culver Co." , a Suprema Corte conclui que "concerns of international comity, respect for the capacities of foreign and transnational tribunals, and sensitivity to the need of the international commerial system for predictibility in the resolution of disputes require that we enforce the parties' agreement, even, assuming that a contrary result would be forthcoming in a domestic context' $t^{\prime 1}$. Pois nota-se que a Suprema Corte abriu mão de uma abordagem fechada, centrada apenas em interesses domésticos, para demonstrar respeito aos seus parceiros internacionais, onde o acordo das partes pela arbitragem de de disputas evolvendo direito da concorrência seja honrado, conferindo segurança nas relações comerciais e previsibilidade de resultados.

Por outro lado, se a preocupação daqueles que rejeitam a arbitragem de disputas envolvendo direitos oriundos de estatutos, tal como a proteção da concorrência, tiver respaldo na perda total de controle da autoridade judiciária, ela é infundada. Conforme alerta a Suprema Corte, a autoridade judiciária competente poderá revisar judicialmente a decisão arbitral para assegurar a observância dos interesses protegidos, quando da execução dessa decisão. ${ }^{92}$

\section{O Direito Internacional Privado Brasileiro dos Contratos e a Arbitragem Comercial}

A lei brasileira de arbitragem é recente, se compararmos, por exemplo, com sua correlata americana, que data de 1925. Isso em muito explica porque os Estados Unidos, hoje, tem uma política bastante liberal com relação à arbitragem, e porque o Brasil só agora começa a aceitar a arbitragem como forma alternativa de solução de diferenças.

\footnotetext{
87 Id.p. 628 .

${ }^{88} \mathrm{Id}$.

89 "[] he pervasive public interest in enforcement of the antitrust laws, and the nature of the claims that arise in such cases, combine to make (...) antitrust claims (...) inappropriatefor arbitration." American Safety Equipment Corp. 2: J.P. Maguire do Co, 391 F.2d 821 (CA2 1968)

90 Scherte : Albento-Culler Ca., 417 U.S. 506, 94 S.Ct 2449, 41 L.Ed.2d 270 (1974).

${ }^{11}$ Mitsubishi Motors Corp. is Soler Cbrysler-Plymouth, 473 U.S. 614, 629 (1985).

92 "Haring fermitted the arbitration to go fonvard, the national courts of the United States will have the opportunity at the award-enforement stage to ensure that the legitimate interest in the enforcement of the antitrust law's has been addressed." Id. p. 638.
} 
Mesmo assim, no Brasil, ainda observa-se um enfoque bastante processual ao instituto da arbitragem, enquanto nos Estados Unidos ele é predominantemente contratual. Eu não vejo impeditivos de uma abordagem contratual à arbitragem brasileira, o que viria de encontro às necessidades daqueles que contratam internacionalmente com e desde o Brasil. No aspecto do direito aplicável especialmente, reconhecer a contratualidade da arbitragem permitiria que a rigidez do artigo 9 da LICC fosse superada, sem maiores alterações no atual quadro normativo. Duas recentes decisões merecem destaque, pois acentuam o aspecto contratual da arbitragem comercial brasileira.

A primeira delas é a decisão do Superior Tribunal de Justiça (STI), em recurso especial de No. $712566 / \mathrm{RJ}^{93}$. Trata-se de contrato de representação comercial entre empresa brasileira e empresa alemã, no qual a primeira teria exclusividade na venda dos equipamentos farmacêuticos produzidos pela segunda. O contrato, celebrado antes da entrade em vigor da Lei 9.307 , de 23 de setembro de 1996, continha cláusula arbitral regida pelo Protocolo de Genebra de 1923. Quando a empresa brasileira propôs ação judicial em 2001, a empresa alemã, em preliminar de contestação, argüiu a existência de cláusula arbitral, razão pela qual a solução judicial estaria afastada, e eventuais conflitos submetidos ao juízo arbitral.

O STJ em decisão inovadora, decidiu pela validade da cláusula arbitral, extinguindo o processo sem julgamento do mérito, nos termos do artigo 267, VII, do Código de Processo Civil brasileiro. Vale destacar a ementa do julgado:

"Processual civil. Recurso especial. Cláusula arbitral. Lei de Arbitragem. Aplicação imediata. Extinção do processo sem julgamento de mérito. Contrato internacional. Protocolo de Genebra de 1923.

- Com a alteração do art. 267, VII, do CPC pela Lei de Arbitragem, a pactuação tanto do compromisso como da cláusula arbitral passou a ser considerada hipótese de extinção do processo sem julgamento do mérito.

- Impõe-se a extinção do processo sem julgamento do mérito se, quando invocada a existência de cláusula arbitral, já vigorava a Lei de Arbitragem, ainda que o contrato tenha sido celebrado em data anterior à sua vigência, pois, as normas processuais têm aplicação imediata.

- Pelo Protocolo de Genebra de 1923, subscrito pelo Brasil, a eleição de compromisso ou cláusula arbitral imprime às partes contraentes a obrigação de submeter eventuais conflitos à arbitragem, ficando afastada a solução judicial.

- Nos contratos internacionais, devem prevalecer os princípios gerais de direito internacional em detrimento da normatização específica de cada país, o que justifica a análise da cláusula arbitral sob a ótica do Protocolo de Genebra de 1923. Precedentes. Recurso especial parialmente conhecido e improvido." (Grifos meus).

\footnotetext{
${ }^{93} \operatorname{Resp} 712566 /$ RJ, Relatora Ministra Nancy Andrighi, Terceira Turma, 18/08/2005, DJ 05.09.2005, p. 407
} 
Chama-se atenção para esta nova postura do STJ com relação à contratos intemacionais com cláusula arbitral. Por um lado, poder-se-ia argumentar que o resultado da decisão está pautado essencialmente no permissivo processual do artigo 267 do CPC, que faz da eleição do juízo arbitral causa de extinção do processo sem julgamento do mérito. Por outro, eu prefiro aqui sublinhar o fundamento contratual da decisão do STJ, que valida a eleição de juízo arbitral para dirimir eventuais conflitos oriundos do contrato.

Percebe-se um desprendimento de preocupações provincianas em levar toda e qualquer disputa à solução judicial e o reconhecimento da arbitragem como forma alternativa de solução de controvérsias.

Por outro lado, o acórdão deixou em aberto a questão sobre a validade de cláusula arbitral de escolha de lei aplicável. Pode-se, entretanto, argumentar que uma vez reconhecida a validade da cláusula arbitral em detrimento da solução judicial, os árbitros estariam livres para validar a escolha de lei aplicável das partes.

Ad arguendo, se força vinculante fosse conferida às decisões dos tribunais brasileiros sobre seus futuros julgados, uma importante regra extraída da decisão do STJ seria: "nos contratos internacionais, devem prevalecer os princípios gerais de direito internacional em detrimento da normatização específica de cada país". Note-se que uma possível interpretação dessa regra permitiria o entendimento que a prática arbitral pode substituir a LICC, que é normatização específica no Brasil. Um tal entendimento seria consentâneo com as necessidades do comércio internacional. Enquanto esperamos posicionamento do STJ a esse respeito, convém lembrar como já decidiu um tribunal estadual em 2002.

Trata-se de agravo de instrumento impetrado por Total Energie, S.N.C. e outra contra Thorey Invest Negócios LTDA, no Primeiro Tribunal de Alçada Civil do Estado de São Paulo ${ }^{94}$ :

1) arbitragem - constitucionalidade - contrato de agência contendo cláusula que impõe a resolução dos conflitos no juízo arbitral, segundo o direito francês - validade - inteligência do art. 2 da lei no. 9.307/96 - incidência do princípio da autonomia da vontade.

A disputa é oriunda de uma ação de cobrança, ajuizada pela agravada Thorey Invest Negócios LTDA contra as agravantes Total Energie, S.N.C. e outra, que rejeita as preliminares argüidas pela prevalência do juízo arbitral. Em sede de agravo, a agravante sustenta que deve prevalecer a cláusula arbitral, estabelecendo que as disputas seriam resolvidas no juízo arbitral. Relata o voto do juiz Waldir de Souza José que o artigo 11 do contrato de agência celebrado entre a agravada e a primeira agravante prevê que "quaisquer litígios decorrentes do ajuste serão definitivamente resolvidos de acordo com o Regulamento de Conciliação e de Arbitragem da Câmara do Comércio Internacional" ${ }^{\prime 25}$.

\footnotetext{
94 Agravo de Instrumento $1111650-0$ - $1^{\circ}$ TACSP - Total Energie/Thorey (J. 24.09.2002).

95 Id. p. 2
} 
A agravante reclama que a regra do artigo 88 do $\mathrm{CPC}$, que trata das hipóteses de competência concorrente da autoridade judiciária brasileira, impõe que a questão seja submetida à justiça brasileira, porque "a obrigação era de ser cumprida em nosso país (artigos 8 e 9 da Lei de Introdução ao Código Civil)" 96 . Por último, alega que a cláusula é inválida porque permite que a demanda seja resolvida com base no direito francês ${ }^{97}$.

Com relação ao argumento do artigo 88 do CPC, o Tribunal entende que não há conflito de competência entre as autoridades brasileira e estrangeira, devendo prevalecer o foro pactuado pelas partes contratantes, o estrangeiro. ${ }^{98}$ Quanto ao direito aplicável, o Tribunal nega incidência da LICC, que "só tem aplicação quando houver omissão ou controvérsia a respeito do direito aplicável à hipótese".?9 Ademais, conforme prevê o artigo 2 da Lei No. 9.307, de 23 de setembro de $1996^{100}$, as partes podem livremente escolher as regras de direito aplicáveis à disputa, afastando o impeditivo constante do artigo 9 da LICC e confirmando a escolha das partes pelo direito francês. Por último, em se tratando de direitos disponíveis, pelo princípio da autonomia da vontade, podem as partes transigir livremente no que tange à forma de solução de suas controvérsias. ${ }^{101}$ Prevalece a argumentação contratual invocada pela agravante. ${ }^{102}$

A decisão do Tribunal de Alçada Civil de São Paulo é pioneira, indo de encontro aos interesses do comércio internacional, de eleição de lei aplicável, sem esperar-e nem mesmo mencionar - a necessidade de ratificação da CIDIP V, que estabelece a autonomia da vontade como elemento de conexão. A opção feita pelo Tribunal foi outra: buscou dentro do próprio ordenamento jurídico brasileiro fundamentos - contratuais - que permitem a escolha de regras aplicáveis à disputa. Uma vez convencionado pelas partes que o direito francês regeria os conflitos oriundos do contrato, e sendo tal escolha ratificada pelo texto da Lei de Arbitragem brasileira, o cumprimento dessa convenção acaba sendo o corolário lógico.

É nesse sentido que a arbitragem comercial vem renovando DIPr brasileiro dos contratos, pois os limites impostos pelos elementos de conexão rígidos do artigo 9 da LICC vêm sendo substituídos pela Lei de Arbitragem. E se de fato há um conflito entre as regras da LICC e as regras da Lei No. 9.307/96, as decisões mais recentes apontam para uma preferência pela Lei de Arbitragem. A flexibilidade oferecida pela Lei No. 9.307 vai de encontro com os interesses do comércio internacional, pautados em previsibilidade e segurança jurídica.

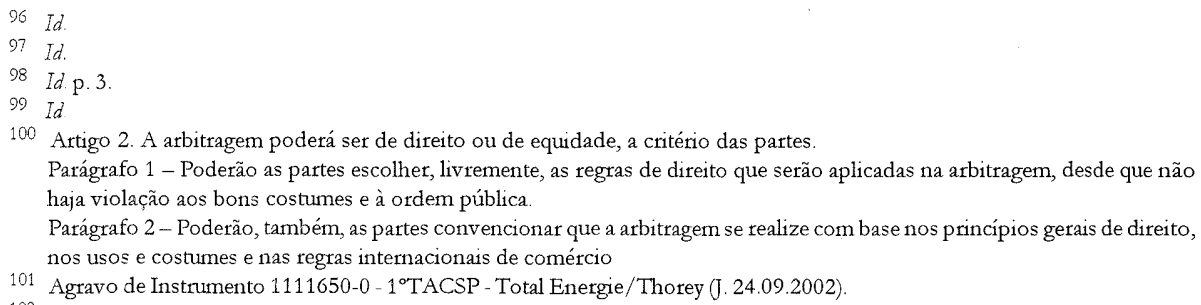




\section{Conclusão}

Os ensinamentos do direito comparado, em conjunto com as possibilidades oferecidas pelo ordenamento jurídico nacional apontam para alternativas à rigidez da LICC relativa às obrigações contratuais. $O$ tratamento da arbitragem como contrato permite que $o$ instituto entre na prática jurídica nacional de forma mais suave, em comparação com o tratamento processual, que concentra suas atenções no rito procedimental diferenciado e na arbitragem enquanto concorrente do juízo estatal.

No DIPr, a consagração da arbitragem como contrato surte efeitos que não passam despercebidos. O mais importante deles, como ressaltei ao longo desse artigo, é a substituição do artigo 9 da LICC pelo artigo 2 da Lei 9.307, de 23 de setembro de 1996. Em outras palavras, a autonomia da vontade, até então vedada no ordenamento jurídico nacional, renasce através da lei de arbitragem, com consequêencias diretas no comércio internacional. O conflito entre a LICC e a Lei de Arbitragem já foi enfrentado nas cortes brasileiras, com resultados surpreendentes. Resta aguardar as próximas decisões judiciais para verificar se o entendimento firmado pelas recentes decisões do STJ e do Tribunal de Allçada Civil do Estado de São Paulo será adotado como a nova praxe brasileira em tema de contratos de arbitragem comercial internacional. 